\title{
Voltammetric Studies of Diazocalix[4]crown-6 for Metal Ion Sensing
}

\author{
Yunyan Dong, Tae Hyun Kim, ${ }^{\dagger, *}$ Chang-Seuk Lee, ${ }^{\dagger}$ Hyun Jung Kim, ${ }^{\dagger}$ Jae Hong Lee, \\ Joung Hae Lee, ${ }^{\S}$ Hasuck Kim, ${ }^{*}$ and Jong Seung Kim ${ }^{\ddagger}, *$ \\ Department of Chemistry, Seoul National University, Seoul 151-747, Korea. ${ }^{*}$-mail: hasuckim@snu.ac.kr \\ ${ }^{\dagger}$ Department of Chemistry, Soonchunhyang University, Asan 336-745, Korea. ${ }^{*}$ E-mail: thkim@sch.ac.kr \\ ${ }^{\ddagger}$ Department of Chemistry, Korea University, Seoul 136-701, Korea. *E-mail: jongskim@korea.ac.kr \\ ${ }^{\S}$ Korea Research Institute of Standards and Science, Taejon 305-600, Korea \\ Received September 6, 2010, Accepted September 20, 2010
}

\begin{abstract}
The complex formation between diazocalix[4]dipropyl (1) and diazocalix[4]crown-6 ether (2) with alkali, alkaline earth and transition metal ions was investigated by voltammetry. Electrochemical properties of compounds $\mathbf{1}$ and 2 and their selectivity toward metal ions were evaluated in $\mathrm{CH}_{3} \mathrm{CN}$ solution by comparison of voltammetric behaviors of two phenols in each compound. Compounds $\mathbf{1}$ and $\mathbf{2}$ showed almost same voltammetric behavior which is two irreversible oxidation peaks caused by intramolecular hydrogen bonding between two phenols in $\mathbf{1}$ and $\mathbf{2}$. While, however, upon interacting with various metal ions, $\mathbf{1}$ with two propyl ether groups showed no significant changes in voltammetry, $\mathbf{2}$ with crown ether group caused significant voltammetric changes upon the addition of $\mathrm{Ba}^{2+}$ to $\mathbf{2}$. Their behavior is closely related to the complex formation by entrapment of metal ion into crown ether cavity, and ion-dipole interaction between metal ion and two phenolic groups in calix[4]crown-6.
\end{abstract}

Key Words: Diazocalixarene, Calixcrown, Voltammetry, Cation recognition

\section{Introduction}

Calix[4]arene has been studied as a useful platform for the development of receptors for metal ions. ${ }^{1}$ Functionalization of upper rim and lower rim in calixarenes enables them to be a variety of derivatives with tunable complexing properties. ${ }^{2}$ For instance, the introduction of crown ether unit to lower rim provides cation binding sites with interesting selectivity, depending on the number of oxygen atoms in the ether bridge. ${ }^{3}$ The calixcrowns are well known as a typical metal ion chelating ligand. Our attention has also focused on the development of a number of calixcrown-based chromogenic, ${ }^{4}$ fluorogenic ${ }^{5}$ and electrochemical chemosensors. ${ }^{6,7}$

Compared with spectrophotometric methods, electrochemical detection has several advantages such as relatively fast response, speed and ease of preparation, low cost, simple instrumentation, wide dynamic range, and especially on-site analysis, which enables the analysis of biologically relevant ions, process control and environmental analysis. ${ }^{6,8}$ Previously, we reported calix[4]crown-6 (2) (Figure 1) functionalized with azo-

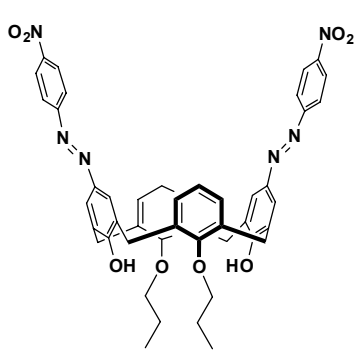

1

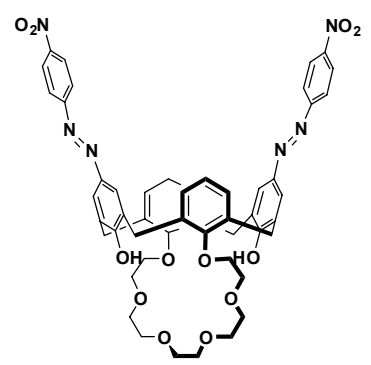

2
Figure 1. Structures of azocalix[4]arenes $\mathbf{1}$ and $\mathbf{2}$. phenol groups, chromophore on the upper rim as signaling unit for the spectrophotometric determination of $\mathrm{Ca}^{2+}$ ion. ${ }^{4 \mathrm{c}}$ Although azocalix[4]crown has been widely used as an metal ion sensing regent for spectrophotometric determination, the sensitivity of the method is low as compared to that of voltammetric method.

As an extension of our studies, we report herein the electrochemical behavior of diazocalix[4]crown-6 (2) using diazocalix[4]dipropyl (1) as a reference in the presence of alkali, alkaline earth and transition metal ions investigated by voltammetry. Compound 1 was prepared to elucidate the role of crown ether unit as a binding site in $\mathbf{2}$ (Figure 1).

\section{Experimental Section}

\section{Synthesis.}

5,17-Bis[(4-nitrophenyl)(azo)phenyl]-25,27-bis(1-propyloxy)calix[4]arene (1): A solution of $3(5.00 \mathrm{~g}, 9.83 \mathrm{mmol})$ in THF $(300 \mathrm{~mL})$ was treated with 4-nitrobenzenediazonium tetrafluoroborate (4.89 g, $20.66 \mathrm{mmol}$ ). The reaction mixture dropwise. The reaction mixture was stirred for an additional $48 \mathrm{~h}$ at $0{ }^{\circ} \mathrm{C}$, treated with $10 \%$ aqueous $\mathrm{HCl}$ solution $(300 \mathrm{~mL})$, and extracted with $\mathrm{CH}_{2} \mathrm{Cl}_{2}(300 \mathrm{~mL})$. The organic layer was washed with $10 \%$ aqueous $\mathrm{HCl}$ solution $(2 \times 300 \mathrm{~mL})$ and dried over $\mathrm{MgSO}_{4}$. Removal of the organic solvent in vacuo afforded a reddish solid. Column chromatography using 4:1 $\mathrm{CHCl}_{3} /$ hexane as an eluent $\left(R_{f}=0.55\right)$ on silica gel gave 1 in $23 \%$ yield. Mp: 272 - $273{ }^{\circ} \mathrm{C}$. FAB MS m/z (M+): calcd, 806.86; found, 806.31. Anal. Calcd for $\mathrm{C}_{46} \mathrm{H}_{42} \mathrm{~N}_{6} \mathrm{O}_{8}$ : C, 68.48; H, 5.21. Found: C, 68.50; $\mathrm{H}, 5.22$. IR (KBr pellet, $\left.\mathrm{cm}^{-1}\right): 325.9(\mathrm{OH}), 1521,1343\left(\mathrm{NO}_{2}\right)$; ${ }^{1} \mathrm{H} \mathrm{NMR}\left(\mathrm{CDCl}_{3}\right) \delta 9.21(\mathrm{~s}, 2 \mathrm{H}, \mathrm{ArOH}), 8.35$ (d, $4 \mathrm{H}, \mathrm{NO}_{2} \mathrm{Ar}-$ $\left.H_{\text {ortho }}, J=8.1 \mathrm{~Hz}\right), 7.96\left(\mathrm{~d}, 4 \mathrm{H}, \mathrm{NO}_{2} \mathrm{Ar}-H_{\text {meta }}, J=8.1 \mathrm{~Hz}\right), 7.81$ (s, $\left.4 \mathrm{H}, \mathrm{N}_{2} \mathrm{Ar}-H_{\text {ortho }}\right), 7.05$ (d, $\left.4 \mathrm{H}, \mathrm{Ar}-H_{\text {meta }}, J=6.9 \mathrm{~Hz}\right), 6.83$ (t, 
$\left.2 \mathrm{H}, \mathrm{Ar}-H_{\text {para }}, J=6.7 \mathrm{~Hz}\right), 4.37\left(\mathrm{~d}, 4 \mathrm{H}, \mathrm{ArCH}_{2} \mathrm{Ar}, J=13.0 \mathrm{~Hz}\right)$, $4.06\left(\mathrm{~s}, 4 \mathrm{H}, \mathrm{OCH}_{2} \mathrm{CH}_{2} \mathrm{CH}_{3}\right), 3.57$ (d, $4 \mathrm{H}, \mathrm{ArCH}_{2} \mathrm{Ar}, J=13.0$ $\mathrm{Hz}), 2.13\left(\mathrm{~m}, 4 \mathrm{H}, \mathrm{OCH}_{2} \mathrm{CH}_{2} \mathrm{CH}_{3}\right), 1.36\left(\mathrm{t}, 6 \mathrm{H}, \mathrm{OCH}_{2} \mathrm{CH}_{2} \mathrm{CH}_{3}\right.$, $J=6.9 \mathrm{~Hz}) ;{ }^{13} \mathrm{C} \mathrm{NMR}\left(\mathrm{CDCl}_{3}\right) \delta 158.7,156.7,152.2,148.3$, 146.1, 132.9, 129.8, 129.2, 126.0, 125.1, 123.2 (ArCH), 79.0 $\left(\mathrm{OCH}_{2} \mathrm{CH}_{2} \mathrm{CH}_{3}\right), 32.0\left(\mathrm{ArCH} \mathrm{H}_{2} \mathrm{Ar}\right), 23.9\left(\mathrm{OCH}_{2} \mathrm{CH}_{2} \mathrm{CH}_{3}\right), 11.3$ $\left(\mathrm{OCH}_{2} \mathrm{CH}_{2} \mathrm{CH}_{3}\right)$.

5,17-Bis[(4-nitrophenyl)(azo)phenyl]-25,27-calix[4]-monocrown-6 (2): The procedures are the same as that for 1 . Yield: 38\%. Mp: $270-271{ }^{\circ} \mathrm{C}$. FAB MS $m / z(\mathrm{M}+)$ : calcd, 924.95; found, 925.00. Anal. Calcd for C50H48N6O12: C, 64.93; H, 5.19. Found: $\mathrm{C}, 64.50 ; \mathrm{H}, 5.17$. IR ( $\mathrm{KBr}$ pellet, $\left.\mathrm{cm}^{-1}\right)$ : 1521 , $1343\left(\mathrm{NO}_{2}\right) ;{ }^{1} \mathrm{H} \mathrm{NMR}\left(\mathrm{CDCl}_{3}\right) \delta 8.50(\mathrm{~s}, 2 \mathrm{H}, \mathrm{ArOH}), 8.40(\mathrm{~d}$, $\left.4 \mathrm{H}, \mathrm{NO}_{2} \mathrm{Ar}-H_{\text {ortho }}, J=8.1 \mathrm{~Hz}\right), 7.97\left(\mathrm{~d}, 4 \mathrm{H}, \mathrm{NO}_{2} \mathrm{Ar}-H_{\text {meta }}, J=8.1\right.$ $\mathrm{Hz}), 7.83$ (s, $\left.4 \mathrm{H}, \mathrm{N}_{2} \mathrm{Ar}-H_{\text {ortho }}\right), 6.96\left(\mathrm{~d}, 4 \mathrm{H}, \mathrm{Ar}-H_{\text {meta }}, J=7.5 \mathrm{~Hz}\right)$, $6.78\left(\mathrm{t}, 2 \mathrm{H}, \mathrm{Ar}-H_{\text {para }}, J=7.5 \mathrm{~Hz}\right), 4.52\left(\mathrm{~d}, 4 \mathrm{H}, \mathrm{ArCH} \mathrm{H}_{2} \mathrm{Ar}, J=\right.$ $13.2 \mathrm{~Hz}$ ), 4.22 (s, $\left.4 \mathrm{H}, \mathrm{ArOCH}_{2} \mathrm{CH}_{2} \mathrm{O}\right), 4.04$ (s, $4 \mathrm{H}, \mathrm{ArOCH}_{2}-$ $\left.\mathrm{CH}_{2} \mathrm{O}\right), 3.91\left(\mathrm{~s}, 4 \mathrm{H}, \mathrm{OCH}_{2} \mathrm{CH}_{2} \mathrm{O}\right), 3.83\left(\mathrm{~s}, 4 \mathrm{H}, \mathrm{OCH}_{2} \mathrm{CH}_{2} \mathrm{O}\right)$, 3.69 (s, $4 \mathrm{H}, \mathrm{OCH}_{2} \mathrm{CH}_{2} \mathrm{O}$ ), 3.54 (d, $4 \mathrm{H}, \mathrm{ArCH}_{2} \mathrm{Ar}, \mathrm{J}=13.2 \mathrm{~Hz}$ ); ${ }^{13} \mathrm{C} \mathrm{NMR}\left(\mathrm{CDCl}_{3}\right): \delta 158.5,156.7,152.4,148.3,146.0,132.7$, 129.3, 125.1, 123.2 ( $\mathrm{ArCH}), 72.0,71.4,71.3\left(\mathrm{OCH}_{2} \mathrm{CH}_{2} \mathrm{O}\right), 31.4$ $\left(\mathrm{ArCH} \mathrm{H}_{2} \mathrm{Ar}\right)$.

Instruments. Electrochemical measurements were carried out with a Model 660 electrochemical workstation (CH Instruments, Austin, TX, USA) using a conventional three-electrode cell. The three-electrode system consists of a glassy carbon working electrode, a Pt wire counter electrode and an $\mathrm{Ag}_{/ \mathrm{Ag}^{+}}(0.1 \mathrm{M})$ reference electrode, separated from the solution by a vycor plug. The surface of the working electrode was polished with $0.3 \mu \mathrm{m}$ alumina (Buehler, Lake Bluff, MN) and rinsed with deionized water. Residual alumina particles were thoroughly removed by placing the electrode in an ultrasonic cleaner for $15 \mathrm{~min}$. Then, the electrode was dried and washed with pure acetonitrile before use. The supporting electrolyte was $0.1 \mathrm{M}$ tetra-n-butylammonium hexa-fluorohphosphate $\left(\mathrm{TBAPF}_{6}\right)$. The concentration of azocalixarenes was $0.1 \mathrm{mM}$ and stock solution of metal perchlorate salts with various concentrations were prepared using acetonitrile.

\section{Results and Discussion}

The synthetic routes for $\mathbf{1}$ and $\mathbf{2}$ are depicted in Scheme 1 . Starting materials 3 and $\mathbf{4}$ were prepared by adapting published procedures. ${ }^{4 \mathrm{c}}$ Diazo coupling reaction using $p$-nitrobenzenediazonium tetrafluoroborate and pyridine gave desired products $\mathbf{1}$ and $\mathbf{2}$ in moderate yield. The presence of the doublets at around $\delta 4.3$ and 3.5 in the ${ }^{1} \mathrm{H}$ NMR spectrum and a resonance at about 32 ppm in the ${ }^{13} \mathrm{C}$ NMR spectrum for compounds $\mathbf{1}$ and $\mathbf{2}$ indicated that they possess the cone conformation.

The binding properties of compounds 1 and $2(0.1 \mathrm{mM})$ towards various metal ions were investigated by cyclic voltammetry (CV) and differential pulse voltammetry (DPV) at glassy carbon electrode in $0.1 \mathrm{M} \mathrm{TBAPF} /$ /acetonitrile solution, by taking advantage of the phenol moieties present at the lower rim, close to propyl ether group or crown ether unit of $\mathbf{1}$ and $\mathbf{2}$. CVs of hosts shows almost same voltammetric behavior which is no reduction peak and two anodic peaks at $0.98 \mathrm{~V}$ and $1.41 \mathrm{~V}$ in $\mathbf{1}$, and $0.92 \mathrm{~V}$ and $1.47 \mathrm{~V}$ in $\mathbf{2}$, respectively (Figure 2). This

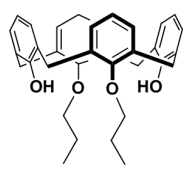

3

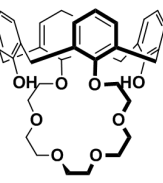

4

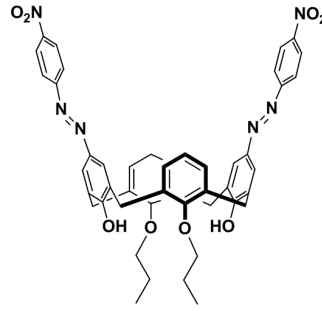

1

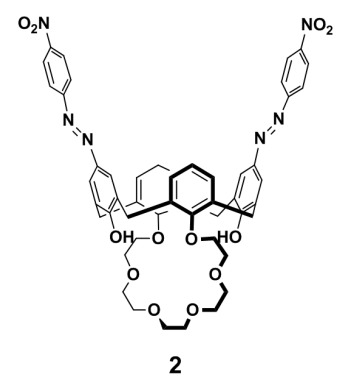

Scheme 1. Synthetic scheme for 1 and 2. Reaction conditions: 4-nitrobenzenediazonium tetrafluoroborate, pyridine, THF.

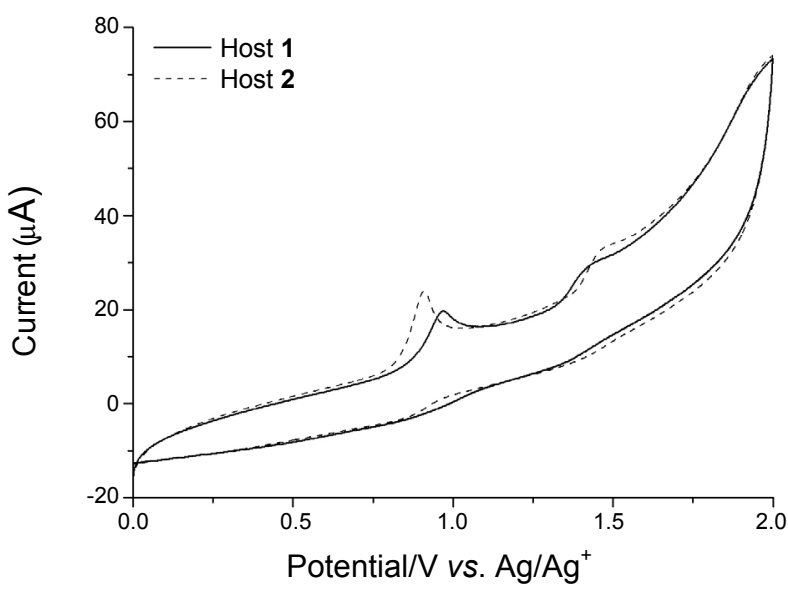

Figure 2. Cyclic voltammograms (CVs) of $0.1 \mathrm{mM} 1$ and 2 at glassy carbon electrode.

could be explained by redox behavior of phenols and intramolecular H-bonding between two phenol moieties in $\mathbf{1}$ and 2. ${ }^{9}$ That is to say, while the oxidation of phenol generally exhibits only one oxidation peak with two electron transfer and proton transfer in organic solution, however, the formation of intramolecular H-bonding between two phenols in $\mathbf{1}$ and $\mathbf{2}$ causes one proton transfer more difficult and the other easier, leading to oxidation peaks at a less positive potential and a more positive potential, respectively. This oxidation behavior of two phenols in $\mathbf{1}$ and $\mathbf{2}$ implies that H-bonding to phenol group can be influenced by complexation with metal ions because the phenols are present at close to crown ether or propyl ether group.

The complexation properties of $\mathbf{1}$ and $\mathbf{2}$ were also investigated by comparing the voltammetric behaviors of phenols in each host with metal ions in DPV which was used to get a better resolution of waves in the same condition with CV. In brief, a constant volume (10 $\mu \mathrm{L}$ per injection) of the metal ion in $0.1 \mathrm{M}$ $\mathrm{TBAPF}_{6}$ supporting electrolyte solution was added into the cell 
(a)

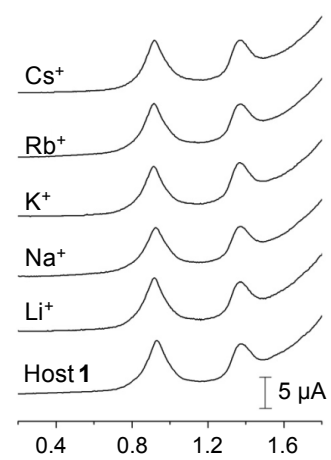

Potential/V vs. $\mathrm{Ag} / \mathrm{Ag}^{+}$

(c)

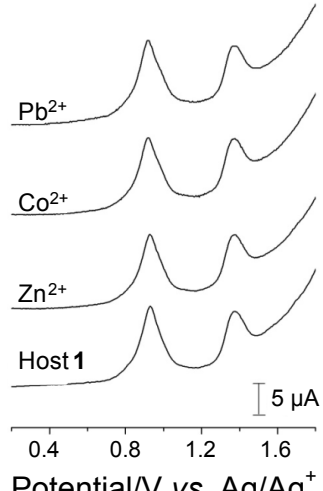

(b)

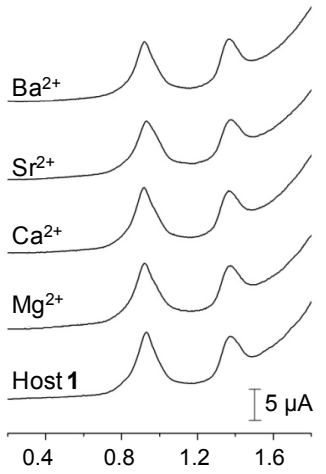

Potential/V vs. Ag/Ag ${ }^{+}$

(d)

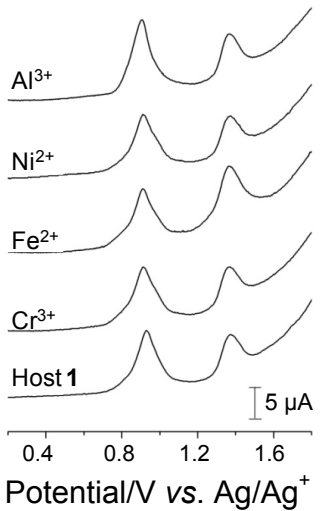

Figure 3. Differential pulse voltammograms (DPVs) of $0.1 \mathrm{mM} 1$ in the presence of $0.1 \mathrm{mM}$ (a) alkali, (b) alkaline earth and (c), (d) some transition metal ions in $\mathrm{CH}_{3} \mathrm{CN}$. Electrolyte, $0.1 \mathrm{M} \mathrm{TBAPF}_{6}$; pulse amplitude, $50 \mathrm{mV}$.

to make 0.1 to 3.0 equivalent of metal ion in the solution. DPVs were recorded after adding stoichiomertric equivalent of metal ions successively to the respective electrochemical solution. DPVs of 1 and $\mathbf{2}$ show almost same voltammetric behaviors with two well-defined anodic peaks, as in CV (Figure 3 and 4). When, however, one equivalent of alkali, alkaline earth and transition metal ions was added to $\mathbf{1}$, which is incapable of encapsulation, no significant change was observed in the peak current or potential (Figure 3). But 2 in the presence of $\mathrm{Ca}^{2+}, \mathrm{Sr}^{2+}$, $\mathrm{Ba}^{2+}$ and $\mathrm{Pb}^{2+}$ shows significant voltammetric changes of DPV in both peak current and potential (Figure 4). The addition of one equivalent of $\mathrm{Ca}^{2+}, \mathrm{Sr}^{2+}, \mathrm{Ba}^{2+}$ and $\mathrm{Pb}^{2+}$ to 2 caused large decrease in anodic peak currents or even disappearance of the original second anodic peak and a new peak at a more positive potential. This is due to the electrostatic interaction between $\mathbf{2}$ and metal ions, leading to electrostatic perturbation of intramolecular H-bonding by encapsulation of metal ions into crown ether and two phenol moieties. Concerning the role of binding site in the complex, the crown ether group of $\mathbf{2}$ acts mainly as a binding site for cation and the phenol moieties of $\mathbf{2}$ constitute the redox active center as well as binding sites. The entrapment of divalent metal ions by the crown loop and hydroxyl groups of phenol moieties may cause deprotonation of phenol groups which makes it difficult to oxidize phenoxide ion to phenoxy radical in the oxidation process because of the repulsion between phenoxy radical and positive metal ion.

(a)

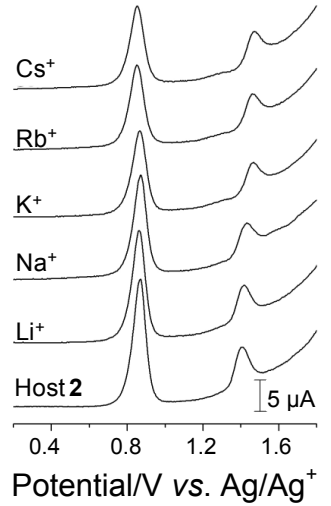

(c)

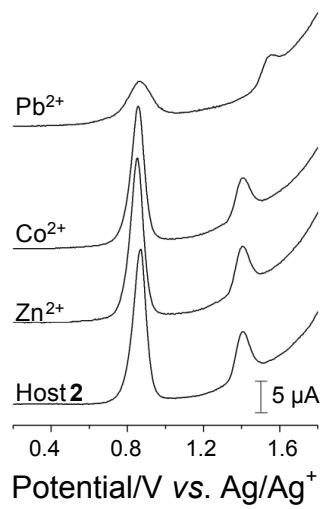

(b)

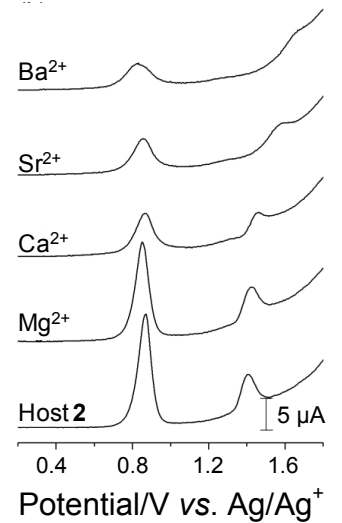

(d)

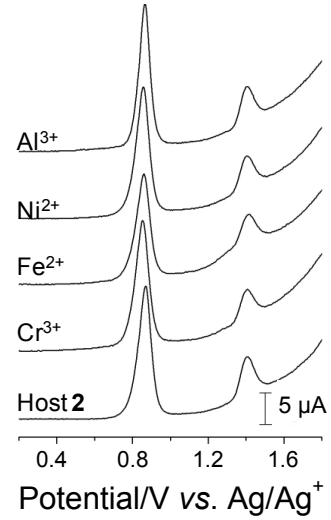

Figure 4. DPVs of $0.1 \mathrm{mM} 2$ in the presence of $0.1 \mathrm{mM}$ (a) alkali, (b) alkaline earth and (c), (d) some transition metal ions in $\mathrm{CH}_{3} \mathrm{CN}$. Electrolyte, $0.1 \mathrm{M} \mathrm{TBAPF}_{6}$; pulse amplitude, $50 \mathrm{mV}$.

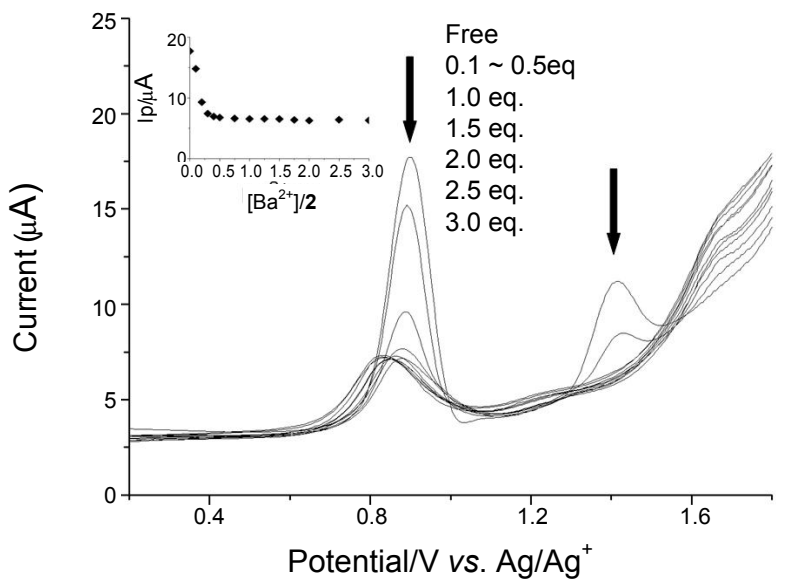

Figure 5. DPVs of $0.1 \mathrm{mM} 2$ in the presence of increasing concentration of $\mathrm{Ba}^{2+}(0.01,0.02,0.03,0.04,0.05,0.1,0.15,0.2,0.25,0.3 \mathrm{mM})$ in $\mathrm{CH}_{3} \mathrm{CN}$. Electrolyte, $0.1 \mathrm{M} \mathrm{TBAPF}_{6}$; pulse amplitude, $50 \mathrm{mV}$; inset is the amperometric titration curve at $0.87 \mathrm{~V}$.

Peak height changes of the first oxidation potential of calix[4]crown in the presence of one equivalent of cations are summarized in Table 1. The current decreasing order of $\mathbf{2}$ of the first peak is $\mathrm{Ca}^{2+}<\mathrm{Sr}^{2+} \approx \mathrm{Pb}^{2+}<\mathrm{Ba}^{2+}$ which is in accordance with the order of potential shift $\left(\Delta \mathrm{E}_{\mathrm{p} 2}=\mathrm{E}_{\mathrm{p} 2}{ }^{*}-\mathrm{E}_{\mathrm{p} 2}\right)$ summarized in Table 2. This indicates 2 binds with metal ions strongly in the 
Table 1. First anodic peak current changes of $\mathbf{1}$ and $\mathbf{2}(0.1 \mathrm{mM})$ to different metal perchlorate salts $(0.1 \mathrm{mM})$ in $\mathrm{CH}_{3} \mathrm{CN}$

\begin{tabular}{cccccccccc}
\hline \multirow{2}{*}{ Compound } & \multicolumn{6}{c}{ Metal-induced peak current changes $\left(\mathrm{I}_{\mathrm{pl}}^{\text {complex }} / \mathrm{f}_{\mathrm{pl}}^{\text {free }}\right)$} \\
\cline { 2 - 9 } & $\mathrm{Li}^{+}$ & $\mathrm{Na}^{+}$ & $\mathrm{K}^{+}$ & $\mathrm{Rb}^{+}$ & $\mathrm{Cs}^{+}$ & $\mathrm{Mg}^{2+}$ & $\mathrm{Ca}^{2+}$ & $\mathrm{Sr}^{2+}$ \\
\hline Host 1 & 0.89 & 0.88 & 0.87 & 0.89 & 0.92 & 0.93 & 0.92 & 0.82 \\
Host 2 & 0.93 & 0.83 & 0.83 & 0.73 & 0.73 & 0.92 & 0.49 & 0.42 \\
\hline \hline & $\mathrm{Ba}^{2+}$ & $\mathrm{Co}^{2+}$ & $\mathrm{Zn}^{2+}$ & $\mathrm{Al}^{3+}$ & $\mathrm{Ni}^{2+}$ & $\mathrm{Fe}^{2+}$ & $\mathrm{Cr}^{3+}$ & $\mathrm{Pb}^{2+}$ \\
Host 1 & 0.85 & 0.88 & 0.88 & 0.96 & 0.85 & 0.85 & 0.86 & 0.92 \\
Host 2 & 0.33 & 0.98 & 1.09 & 1.15 & 1.04 & 0.91 & 1.01 & 0.40 \\
\hline
\end{tabular}

Table 2. Peak potential differences between free host and metal ion complexations determined by differential pulse voltammetry

\begin{tabular}{ccccc}
\hline \multirow{2}{*}{ Metal ions } & \multicolumn{4}{l}{ Potential difference $\left(\Delta \mathrm{E}_{\mathrm{p} 2}=\mathrm{E}_{\mathrm{p} 2}{ }^{*}-\mathrm{E}_{\mathrm{p} 2}\right)^{a}(\mathrm{mV})$} \\
\cline { 2 - 5 } & $\mathrm{Ca}^{2+}$ & $\mathrm{Sr}^{2+}$ & $\mathrm{Ba}^{2+}$ & $\mathrm{Pb}^{2+}$ \\
\hline Host 1 & -8 & 4 & -8 & 4 \\
Host 2 & 52 & 176 & 256 & 156
\end{tabular}

${ }^{\bar{a}} \mathrm{E}_{\mathrm{p} 2} *$ and $\mathrm{E}_{\mathrm{p} 2}$ represent new peak potential of each cation-host complex and second peak potential of each host, respectively.

order of $\mathrm{Ba}^{2+}>\mathrm{Sr}^{2+} \approx \mathrm{Pb}^{2+}>\mathrm{Ca}^{2}$.

In order to get a further study of the electrochemical recognition phenomenon, complexion behavior of $\mathbf{2}$ with increasing amounts of $\mathrm{Ba}^{2+}$ was carried out. Figure 5 shows the effect of concentration of $\mathrm{Ba}^{2+}$. With increasing the amounts of $\mathrm{Ba}^{2+}$, the oxidation peaks of 2 at $0.87 \mathrm{~V}$ and especially $1.41 \mathrm{~V}$ decrease, respectively. A new peak at more positive potentials grows at the expense of the original corresponding peaks of free host. The peak current $\left(\mathrm{I}_{\mathrm{p} 1}\right)$ at $0.87 \mathrm{~V}$ decreases quantitatively by increasing the concentration of $\mathrm{Ba}^{2+}$ and gradually reaches to the minimum value at around one equivalent (Figure 5 inset).

\section{Conclusions}

The electrochemical behavior of calix[4] arene 2 bearing nitrophenylazo and crown- 6 and its binding ability toward alkali, alkaline earth and transition metal ions were carried out by voltammetry, compared to calix[4]arene 1 containing propyl ether groups instead of crown ether group. 2 showed a selective change in voltammetric behavior toward the $\mathrm{Sr}^{2+}, \mathrm{Pb}^{2+}, \mathrm{Ca}^{2}$ and especially $\mathrm{Ba}^{2+}$ cation in $\mathrm{CH}_{3} \mathrm{CN}$. This is mainly due to the presence of crown ether group and two proximal OHs of the calix[4]arene framework. Control experiments with $\mathbf{1}$ devoid of crown ether group confirm that crown ether group, as well as two phenol groups, in $\mathbf{2}$ take part in the cation complexation.

Acknowledgments. This work was supported by CRI project (2010-0000728) of National Research Foundation of Korea, and following are results of a study on the "Human Resource De- velopment Center for Economic Region Leading Industry" Project, supported by the Ministry of Education, Science \& Technology (MEST) and National Research Foundation of Korea (NRF).

\section{References}

1. (a) Gutsche, C. D. Royal Society of Chemistry (Great Britain), Calixarenes: an introduction, 2nd ed.; RSC Publishing: Cambridge, 2008; p 276. (b) Mandolini, L.; Ungaro, R. Calixarenes in Action; Imperial College Press: Distributed by World Scientific Pub. Co.: London River Edge, NJ, 2000; p 271. (c) Lee, S. H.; Kim, H. J.; Lee, Y. O.; Vicens, J.; Kim, J. S. Tetrahedron Lett. 2006, 47, 43734376. (d) Lee, M. H.; Quang, D. T.; Jung, H. S.; Yoon, J.; Lee, C. H.; Kim, J. S. J. Org. Chem. 2007, 72, 4242-4245.

2. (a) Bew, S. P.; Brimage, R. A.; L'Hermite, N.; Sharma, S. V. Org. Lett. 2007, 9, 3713-3716. (b) Gaeta, C.; Troisi, F.; Neri, P. Org. Lett. 2010, 12, 2092-2095. (c) Kim, J. S.; Lee, S. Y.; Yoon, J.; Vicens, J. Chem. Commun. 2009, 4791-4802. (d) Metay, E.; Duclos, M. C.; Pellet-Rostaing, S.; Lemaire, M.; Kannappan, R.; Bucher, C.; SaintAman, E.; Chaix, C. Tetrahedron 2009, 65, 672-676. (e) Rozhenko, A. B.; Schoeller, W. W.; Letzel, M. C.; Decker, B.; Agena, C.; Mattay, J. Chem.-Eur. J. 2006, 12, 8995-9000. (f) Shahgaldian, P.; Sclotti, M. A.; Pieles, U. Langmuir 2008, 24, 8522-8526.

3. Asfari, Z. Calixarenes 2001; Kluwer Academic Publishers: Dordrecht, Boston, 2001; p 683.

4. (a) Kim, H. J.; Kim, S. H.; Kim, J. H.; Anh, L. N.; Lee, J. H.; Lee, C. H.; Kim, J. S. Tetrahedron Lett. 2009, 50, 2782-2786. (b) Lee, J. W.; Park, S. Y.; Cho, B. K.; Kim, J. S. Tetrahedron Lett. 2007, 48, 2541-2546. (c) Kim, J. Y.; Kim, G.; Kim, C. R.; Lee, S. H.; Lee, J. H.; Kim, J. S. J. Org. Chem. 2003, 68, 1933-1937.

5. (a) Park, S. Y.; Yoon, J. H.; Hong, C. S.; Souane, R.; Kim, J. S.; Matthews, S. E.; Vicens, J. J. Org. Chem. 2008, 73, 8212-8218. (b) Choi, J. K.; No, K.; Lee, E. H.; Kwon, S. G.; Kim, K. W.; Kim, J. S. Supramol. Chem. 2007, 19, 283-286. (c) Choi, J. K.; Kim, S. H.; Yoon, J.; Lee, K. H.; Bartsch, R. A.; Kim, J. S. J. Org. Chem. 2006, 71, 8011-8015. (d) Lee, S. H.; Kim, S. K.; Bok, J. H.; Lee, S. H.; Yoon, J.; Lee, K.; Kim, J. S. Tetrahedron Lett. 2005, 46, 8163-8167. (f) Kim, S. K.; Lee, S. H.; Lee, J. Y.; Lee, J. Y.; Bartsch, R. A.; Kim, J. S. J. Am. Chem. Soc. 2004, 126, 16499-16506.

6. (a) Kim, T. H.; Kim, J. S.; Kim, H. J. Electroanal. Chem. 2008, 615, 103-109. (b) Choi, Y.; Kim, H.; Lee, J. K.; Lee, S. H.; Lim, H. B.; Kim, J. S. Talanta 2004, 64, 975-980.

7. (a) Sessler, J. L.; Kim, S. K.; Gross, D. E.; Lee, C. H.; Kim, J. S.; Lynch, V. M. J. Am. Chem. Soc. 2008, 130, 13162-13166. (b) Bouhroum, S.; Kim, J. S.; Lee, S. W.; Thuery, P.; Yap, G.; Arnaud-Neu, F.; Vicens, J. J. Incl. Phenom. Macro. 2008, 62, 239-250. (c) Kim, S. K.; Lee, J. K.; Lim, J. M.; Kim, J. W.; Kim, J. S. Bull. Korean Chem. Soc. 2004, 25, 1247-1250. (d) Kim, S. K.; Lee, J. K.; Lee, S. H.; Lim, M. S.; Lee, S. W.; Sim, W. B.; Kim, J. S. J. Org. Chem. 2004, 69, 2877-2880. (e) Kim, S. K.; Kim, S. H.; Kwon, S. G.; Lee, E. H.; Lee, S. H.; Kim, J. S. Bull. Korean Chem. Soc. 2004, 25, 1244-1246. (f) Lee, J. K.; Kim, S. K.; Bartsch, R. A.; Vicens, J.; Miyano, S.; Kim, J. S. J. Org. Chem. 2003, 68, 6720-6725.

8. Kaifer, A. E.; Gómez-Kaifer, M. Supramolecular Electrochemistry; Wiley-VCH: Weinheim, New York, 1999; p 241.

9. (a) Dong, Y. Y.; Kim, T. H.; Kim, H. J.; Lee, M. H.; Lee, S. Y.; Mahajan, R. K.; Kim, H.; Kim, J. S. J. Electroanal. Chem. 2009, 628, 119-124. (b) Kim, T. H.; Kim, S. H.; Van Tan, L.; Dong, Y. Y.; Kim, H.; Kim, J. S. Talanta 2008, 74, 1654-1658. 